\title{
CALCIUM, POTASSIUM AND MAGNESIUM TREATMENT OF Chrysanthemum morifolium cv. "Bi Time" AND CALLOGENESIS in vitro
} \author{
Melo ${ }^{1 *}$ \\ ${ }^{1}$ Depto. de Ciências Biológicas - USP/ESALQ, C.P. 9 - CEP: 13418-900 - Piracicaba, SP. \\ ${ }^{2}$ Depto. de Ciências Exatas - USP/ESALQ. \\ ${ }^{3}$ FAPESP Fellow. \\ *Corresponding author<mmelo@esalq.usp.br>
}

Fábio Borgatto ${ }^{1,3}$; Carlos Tadeu dos Santos Dias²; Antônio Francisco Campos Amaral'; ${ }^{1}$ Murilo

\begin{abstract}
The chemical composition and vegetative vigor of the donor plant are essential for the satisfactory performance of explants in vitro. In order to test the effect of potassium, calcium and magnesium nutritional status of Chrysanthemum morifolium plants on callogenesis in vitro, pot plants growing in sand were irrigated with nutrient solution containing different levels of potassium $\left(0 ; 58.5 ; 117\right.$ and $\left.234 \mathrm{mg} \mathrm{L}^{-1}\right)$, calcium $(0 ; 50$; 100 e $\left.200 \mathrm{mg} \mathrm{L}^{-1}\right)$ and magnesium $\left(0 ; 12 ; 48\right.$ e $\left.96 \mathrm{mg} \mathrm{L}^{-1}\right)$. After 30 and 45 days, explants (shoot segments and leaf discs) were collected, desinfected and inoculated on MS solid medium supplemented with $0.1 \mathrm{mg} \mathrm{L}^{-1}$ of kinetin and $5.0 \mathrm{mg} \mathrm{L}^{-1}$ of nafthalene acetic acid for callogenesis induction. Callogenesis evaluated as callus fresh weight was affected by nutrients treatment. Callus growth on leaf explants was inversely proporcional to potassium concentration and directly proportional to magnesium concentration in shoot explants. The calcium effect on callogensis of leaf explants was dependent on treatment duration. For 30 days treatment callogenseis was inversely related to calcium concentration and after 45 days was directly related to calcium concentration. Key words: matrix plant, mineral nutrition, tissue culture
\end{abstract}

\section{TRATAMENTO DE PLANTAS MATRIZES DE Chrysanthemum morifolium cv. "Bi Time" COM Ca ${ }^{2+}, \mathrm{K}^{+} \mathrm{E} \mathrm{Mg}^{2+} \mathrm{E}$ CALOGÊNESE in vitro}

\begin{abstract}
RESUMO: A composição química e o vigor vegetativo de plantas matrizes são essenciais no desenvolvimento de explantes in vitro. Com o objetivo de testar o efeito do estado nutricional de plantas matrizes de Chrysanthemum morifolium no processo de calogênese in vitro, plantas crescendo em vasos contendo areia lavada foram irrigadas com soluções nutritivas contendo diferentes concentrações de cálcio $(0,50,100$ e $\left.200 \mathrm{mg} \mathrm{L}^{-1}\right)$, potássio $\left(0,58,5,117\right.$ e $\left.234 \mathrm{mg} \mathrm{L}^{-1}\right)$, e magnésio $\left(0,12,48\right.$ e $\left.96 \mathrm{mg} \mathrm{L}^{-1}\right)$. Aos 30 e 45 dias de duração do tratamento com solução nutritiva, explantes (segmento caulinar e foliar) das matrizes foram coletados, desinfestados e inoculados em meio de cultura MS sólido suplementado com $0,1 \mathrm{mg} \mathrm{L}^{-1}$ de Kin e 5,0 $\mathrm{mg} \mathrm{L}^{-1} \mathrm{NAA}$. A calogênese foi afetada pelos tratamentos com os diferentes níveis dos nutrientes. $\mathrm{O}$ crescimento de calos a partir de explantes foliares foi inversamente proporcional ao teor de potássio e diretamente proporcional aos de magnésio em explantes caulinares. O efeito do cálcio na calogênese em explantes foliares mostrou ser dependente da duração do tratamento. Nos testes com 30 dias de duração a calogênese foi inversamente proporcional, e naqueles com 45 dias de duração demonstrou ser diretamente proporcional aos níveis de cálcio.

Palavras-chave: planta matriz, nutrição mineral, cultura de tecido
\end{abstract}

\section{INTRODUCTION}

Chrysanthemum morifolium Ramat, currently classified as Dendranthema grandiflora (Anderson, 1987), belonging to the Asteraceae family, classified before as Compositae (Salinger, 1991), is a complex hybrid. Its popularity as cutting flower has led to the introduction of thousands of new cultivars of large flower diversity (Cockshull, 1985).

The brazilian Chrysanthemum flower production, besides being sufficient for the internal market supply, is also exported to Argentina as cut flowers and to Holland as potted plants. The brazilian commercial segment of flowers and ornamental plants is presently showing an average yearly increase of $30 \%$. The São Paulo State, the growers leading state, holds $80 \%$ of the total production.

The cut flower industry, perhaps differently from any other industry, needs to routinely attend the continuous flower consumer demands. Consumer preferences change and show new and sometimes uncommon features. Therefore, the priority of the flower and ornamental plant biotechnology segments should be the generation of novel plant and flower types (Hutchinson et al., 1982). In this context, plant organs, tissues and cell cultures present a great potential.

Several factors, such as genotype, culture medium, physical and environmental growth conditions, 
and factors inherent to the explants are expected to affect morphogenesis in vitro and plant development. Factors related to the explants include the physical nature (age and type), as well as the growing conditions of the plants providing the explants to be cultured in vitro (George \& Sherrinton, 1984). In spite of being a known factor affecting organ and tissue behavior in vitro, studies investigating these processes are not numerous. The mineral composition of the donor plant tissues, particularly calcium, potassium and magnesium plays a fundamental role in tissue and cell growth response in vitro (Montoro et al., 1995; Hepler \& Wayne, 1985).

Calcium is thought to function as a secondary messeger in the transmission and transduction of several enviromental signals acting as intracelular metabolic agent. Due to its high affinity to calmodulin and other calcium-binding-proteins, this nutrient might directly control several physiological processes (Hepler \& Wayne, 1985).

Reports on Chrysanthemum mineral nutrition indicate variability of calcium concentration in the leaves and plants along the growth cycle. However the mangnitude of this variability has been shown to be tissue-dependent (Lima, 1987).

Potassium is essential for membrane transport processes, stomata opening, plant cell osmotic potential, and is also an activator of several enzymes, mainly those involved in plant cell reopiration and photosynthesis (Marschner, 1995).

Magnesium, besides being the central atom of the chlorophyll molecule, representing approximately 10 $\%$ of the total foliar magnesium (Hopkins, 1995), is also a cofactor of most enzymes acting on phosphorylated substrates, making it very important in energy metabolism. Enzymatic reactions acting on the carboxylic group, nucleotide transfer, some dehydrogenases, mutases and lyases are also processes stimulated by magnesium (Mengel \& Kirkby, 1987).

When an explant is inoculated in vitro, diverse responses are expected and factors determining chemical and physiological charachteristics of the tissues donor plants seem to be crucial. This work studied the influences of the treatment of Chrysanthemum donor plants with nutrient solutions containing distinct calcium, potassium and magnesium levels, on the callogenesis process in vitro.

\section{MATERIAL AND METHOD}

Plant cuttings of Chrysanthemum morifolium Ramat cv. "Bi Time" with four pairs of leaves were planted in one litter plastic pots containing washed sand, transferred to a greenhouse, submitted to $16 / 8$ hours (light/dark) photoperiod, and to tap water irrigation for 15 days. Treatments of different $\mathrm{Ca}^{2+}, \mathrm{K}^{+}$and $\mathrm{Mg}^{+}$levels were then initiated by irrigating the plants with $100 \mathrm{~mL}$ of nutrient solution (Lima et al., 1987) contaning 0, 50,
100 and $200 \mathrm{mg} \mathrm{L}^{-1}$ of calcium, 0, 58.5, 117 and $234 \mathrm{mg}$ $\mathrm{L}^{-1}$ of potassium, and $0,12,48$ and $96 \mathrm{mg} \mathrm{L}^{-1}$ of magnesium.

The experimental design was in randomized blocks with twenty replicates and twelve treatments. To evaluate treatment duration effects, two plants were grown in each pot and sampling was made 30 and 45 days after treatment started. Leaf discs of $1 \mathrm{~cm}$ diameter and internodal segments $1 \mathrm{~cm}$ long, were used as explants.

In order to minimize any phenological effect on callogenesis response, leaf explants were always taken from mature and total expanded leaves, and stem explants from their corresponding internodal region. For Chrysanthemum these leaves are the third pair of leaves counted from the plant apex.

After assepsy under laminar flow with $3 \%$ sodium hypochloryte solution containing $0.1 \%(\mathrm{v} / \mathrm{v})$ Tween-20, during 30 minutes under agitation. Explants were then rinsed twice with autoclaved distilled water and inoculated on Murashige and Skoog (1962) culture medium, supplemented with $30 \mathrm{mg} \mathrm{L}^{-1}$ sucrose, $0.1 \mathrm{mg} \mathrm{L}^{-1}$ kinetin, $5.0 \mathrm{mg} \mathrm{L}^{-1}$ naphthalene acetic acid. For callogenesis induction the $\mathrm{pH}$ was ajusted to 5.8 with $\mathrm{KOH}$.

The culture was kept in a growth chamber with a light intensity of $50.8 \mathrm{mmol} \mathrm{m}^{-2} \mathrm{~s}^{-1}$ and a temperature of $25+2^{\circ} \mathrm{C}$.

Callogenesis induction and callus growth were evaluated based on callus fresh weight thirty days after inoculation. Correction for explant weight on callus weight was made by subtracting its weight from the respective callus weight. Data were submitted to variance and regression anlyses, according to Gomes (1990).

\section{RESULTS AND DISCUSSION}

\section{Calcium}

No visible calcium deficiency or toxicity symptoms were observed on the plants during the sixty day period of treatments with nutrient solutions containing variable calcium levels. This situation is highly desirable in relation to the objectives of this research, since it was our interest to test plants with calcium deficiency or toxicity levels enough to cause only metabolic imperfections before morphological deficiency and toxicity manifested.

The effect of treated donor Chrysanthemum plants with variable levels of calcium during forty five days on callogenesis induction and callus growth are shown in Figures 1 (internodal explants) and 2 (leaf explants).

Callogenesis of internodal explants was affected by high and low levels of calcium. The duration of the treatment did not seem to influence callogenesis on this explant. Even though callogenesis might be related to mass or number of cells of the explant, stem explants had only half of the callogenesis observed for leaf explants.

Callus fresh matter accumulation on the foliar explant was proportional to the concentration of calcium 
in nutrient solutions for the thirty day period $(Y=1.924$ $\left.-0.0013 X ; R^{2}=0.2364\right)$ and directly proportional for the forty-five day period $\left(Y=1.48+0.001 X ; R^{2}=0.6677\right)$.

The results of this study are similar to those of Frett \& Dirr (1986) working with Petunia hibrida. Those authors attributed the calcium effect on callogenesis to the decrease in lignification of the cell wall caused by low level of calcium, facilitating callus initiation and growth in vitro.

From the calcium translocation point of view, it is suggested that callogenesis induction and/or callus growth, are directly proportional to the calcium concentration in plant tissue explants. Since calcium is poorly translocated, the amount transported in the xylem tends to accumulate in leaves. Callogenesis was, therefore, more intense on leaf explants. Redistribution of calcium through phloem is dependent on the levels of organic acid and inorganic phosphate in tissues where they form chelates with calcium (Jeschke et al., 1986). Since photosynthesis is how organic acid concentration increases in plant tissue, mainly in leaves, calcium translocation becomes dependent on photosynthesis intensity. In this sense, the increased translocation of calcium through the phloem, back to roots, generates a calcium uptake mecanism control (Cooper \& Clarkson, 1989) eventually regulating the level of calcium in plant tissue. Considering the Chrysanthemum growth cycle, higher photosynthesis intensity is certainly expected to occur during the active growth period, which corresponds to the initial growth period of the crop. This sequence of metabolic events may explain the contrasting results found for callogenesis on leaf explants for thirty day as compared to forty-five day treatments. Similary, the higher callogenesis on this explant is probably due to the higher calcium level in this tissue as compared to that occurring in stem explants.

Conversely, callus growth could be negatively affected by high levels of calcium in the tissue, since high calcium concentration inhibits enzyme activities, also affecting magnesium uptake, which is associated to protein synthesis and activation of enzymes closely related to celular growth (Marschner, 1995). The increase

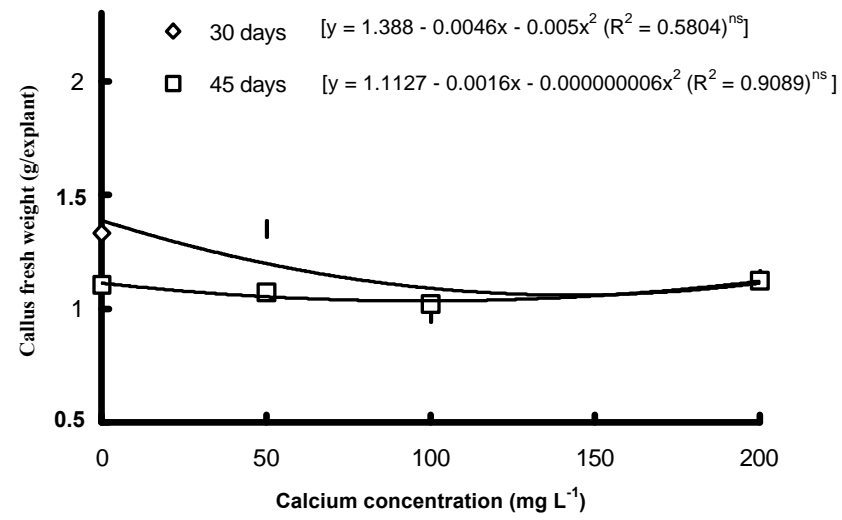

Figure 1 - Callus weight of Chrysanthemum morifollium cv. stem explants in response to $\mathrm{Ca}$ concentration. ${ }^{\text {ns Non significant }}$ of a specific nutrient concentration can stimulate cell and tissue growth, but it can at the same time induce deficiencies of other nutrients by the dilution effect (Marschner, 1995). This should always be taken into account when interpreting the nutrient content and antognism during nutrient uptake.

\section{Potassium}

Only donor plants treated with nutrient solution without potassium showed visible potassium deficiency symptoms after forty five days of treatment. Leaf chlorosis followed by necrosis, mainly on leaf tips and edges were observed. These symptoms were similar to those reported for Chrysanthemum by Lima (1987).

The effect of Chrysanthemum donor plant treatment with nutrient solutions containing different levels of potassium on the callogenesis are shown in Figures 3 (caulinar explant) and 4 (foliar explant).

The callogenesis on leaf explants was proportional to potassium levels in the nutrient solution for the thirty and forty five day long treatments and followed the linear regression equation $Y=0.2394$ $0.0002 X\left(R^{2}=0.7119\right)$. Callogenesis was inversely proportional to potassium concentration in the nutrient solution.

Yield reduction may be associated not only to the toxicity of a given nutrient, but also to the deficiency of other nutrients causing an ionic unbalance among nutrients (Marschner, 1995). In this case high potassium concentration in the tissue could have interferred on the uptake and availability of calcium and/or magnesium, therefore affecting callogenesis and/or callus growth.

The uniform results for both, potassium level and treatment duration for stem explants, may be associated to the high potassium translocability, providing in any condition a constant potassium concentration in the stem tissue. Accordint to Mengel \& Kirkby (1987) the high potassium mobility through the plant toward the young parts of the plant generates a potassium redistribution from mature to young tissue. This could explain the low callogenesis of stem explants in treatments containing low potassium concentration for the forty-five day long

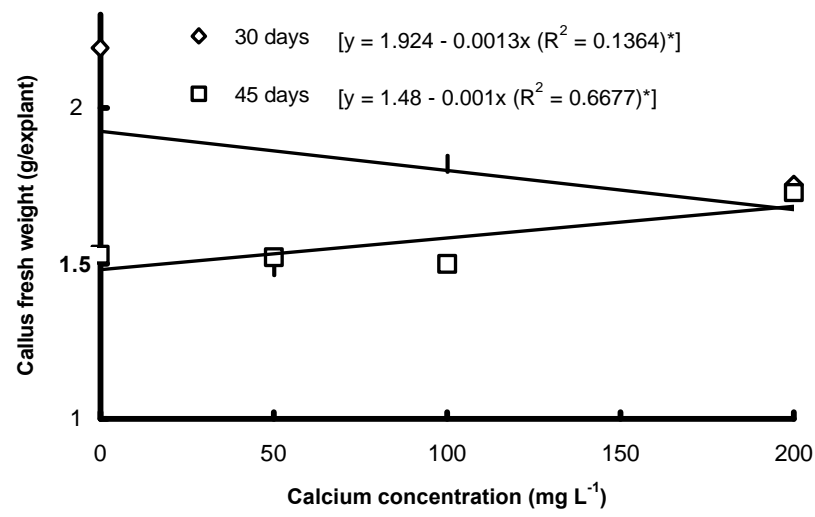

Figure 2 - Callus weight of Chrysanthemum morifollium cv. leaf explants in response to $\mathrm{Ca}$ concentration. *Significant at $5 \%$ by $\mathrm{F}$ test. 
treatment, reflecting the many cellular metabolic functions of potassium. As pointed out by Marschner (1995) potassium deficient plants accumulate carbohydrates and soluble nitrogenous compounds such as amides, aminoacids, nitrate, putrescine, agmatine, and $\mathrm{N}$ carbamyl putrescine. These alternatives on the carbohydrate metabolism are associated with the potassium requirement by some regulatory enzymes such as pyruvate kinase and phosphofructokinase, which regulate the metabolite flow of glycolisis.

Potassium also activates enzymes involved in photosynthesis, where its essential function on $\mathrm{CO}_{2}$ fixation is clearly demonstrated with isolated intact chloroplasts. External increase of potassium concentration levels to concentration, similar to the intact cell cytosol, stimulates $\mathrm{CO}_{2}$ fixation three fold. The counterbalance of the proton pumping into thylakoids during $\mathrm{CO}_{2}$ fixation is also influenced by potassium concentration. Increase of potassium concentration to values $100 \mathrm{mmol} \mathrm{L}^{-1}$ higher than normal values stimulates $\mathrm{CO}_{2}$ fixaton, promoting therefore high cellular growth.

Potassium and other organic and inorganic anions represent the main solutes required in the vacuole to promote cell expansion. According to Leigh \& Wyn Jones (1984) whenever the potassium concentration in the vegetal tissue is low, its concentration in the cell vacuole may become lower than the critical value, causing reduction of the cytosol potassium concentration to levels close to those affecting potassium-dependent metabolic processes.

Taking into consideration that potassium is involved in the efficiency of the t-RNA binding to ribossomes during protein synthesis, the low acumulation of callus fresh matter in treatments containing low levels of potassium may be related to low protein synthesis by the callus cells.

\section{Magnesium}

None of the Chrysanthemum treated plants with nutrient solution containing different levels of magnesium showed deficiency or toxicity symptoms of magnesium. The effects of the magnesium treatment on callogenesis

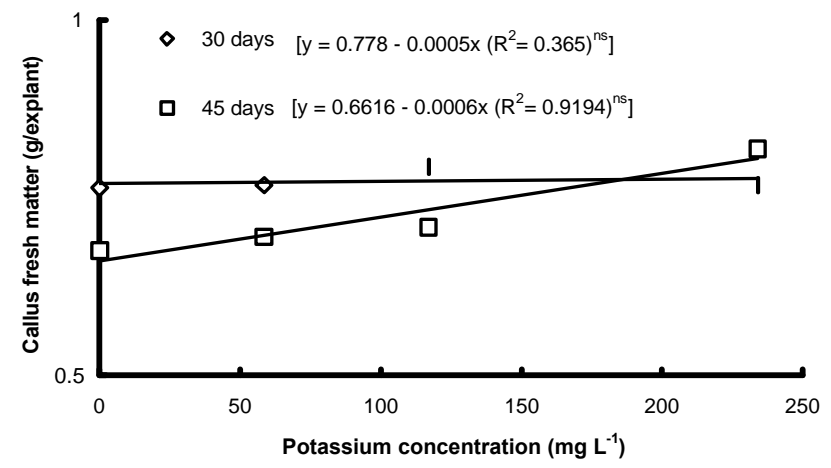

Figure 3 - Callus weight of Chrysanthemum morifollium cv. stem explants in response to $\mathrm{K}$ concentration. ns Non significant. are shown in Figures 5 (caulinar explant) and 6 (foliar explant). Increasing levels of magnesium had an effect on callus fresh matter accumulation for the stem explants only at the thirty day duration treatment. The linear equation $Y=0.4955+0.003 X\left(R^{2}=0.7219\right)$ fits this callogenesis induction, the callus production being proportional to levels of magnesium in the nutrient solution.

The results for stem explants were different from those found by Defavari (2000) working with Bauhínia forficata, who observed that callogenesis was inversely proportional to the level of magnesium in the nutrient solution. However, He et al. (1989) investigating the effect of magnesium concentration in culture medium, observed that wheat callogenesis was directly related to magnesium levels.

Even though magnesium is highly translocable, its function as chlorophyll component and participation in the $\mathrm{CO}_{2}$ fixation mechanism, is certainly the role causing an unsatisfactory development of plants growing under low magnesium conditions. As these plants carry out lower levels of photosynthesis, they eventually accumulate less cellular material and less carbon skeleton. With little carbon skeleton availability, the cell metabolism, mainly for nitrogen, would considerably be affected causing an unbalance of the cellular $\mathrm{C} / \mathrm{N}$ ratio.

The participation of magnesium on enzymatic reactions transferring phosphates, mainly in glycolisis and in pentose phosphate pathway during carbohydrate oxidation, together with the magnesium contribution to efficient $\mathrm{CO}_{2}$ fixation, are crucial for plant cell metabolism and energy balance. Of equal importance is the function of magnesium in stabilizing ribosome subunits. Magnesium-deficient plants would synthesize less protein, some with enzyme function, therefore compromising the carbon nitrogen metabolism and plant growth and development. This process was evidenced by Defávari (2000) showing that Bauhinia forficata donor plants treated with low magnesium nutrient solution presented less protein content.

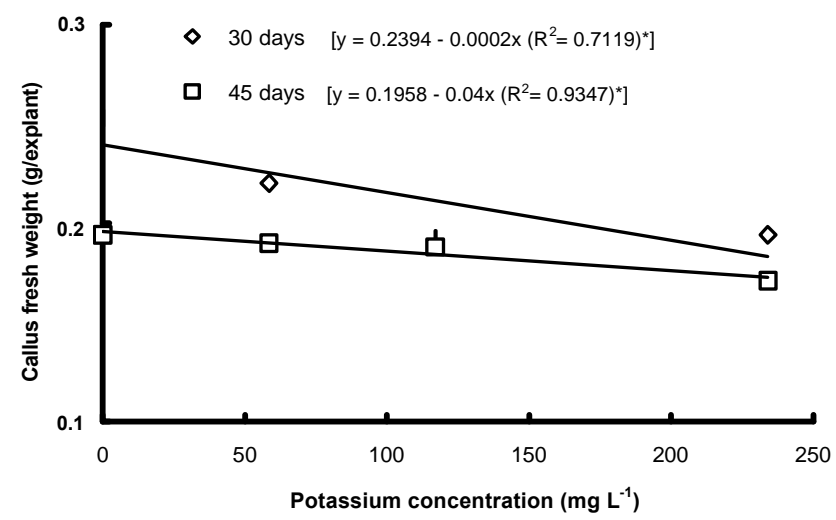

Figure 4 - Callus weight of Chrysanthemum morifollium cv. leaf explants in response to $\mathrm{K}$ concentration. *Significant at $5 \%$ by $\mathrm{F}$ test. 


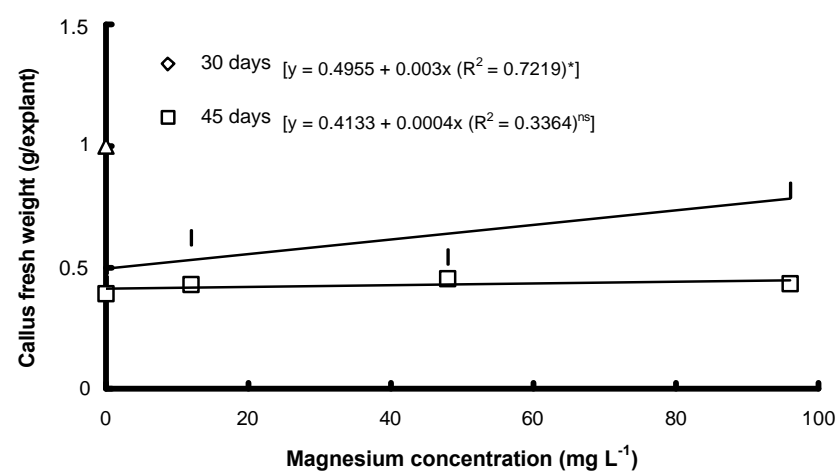

Figure 5 - Callus weight of Chrysanthemum morifollium cv. stem explants in response to $\mathrm{Mg}$ concentration.

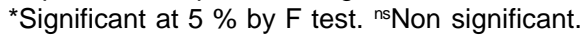

Possible magnesium substitution by maganese in enzymatic reactions, its high translocability and eventual low magnesium requeriment by Chrysanthemum plants, may have contributed to the magnesium effect on callogenesis by leaf explants to become less significant.

\section{CONCLUSION}

Explants of Chrysanthemum morifolium Ramat cv. "Bi Time" treated with nutrient solutions containing different levels of potassium, calcium and magnesium showed variable callogenesis and callus growth. Callogenesis on leaf explants is directly proportional to levels of calcium, inversely proportional to levels of potassium and not influenced by the levels of magnesium in the nutrient solutions. Callogenesis by stem explants is only affected by magnesium levels. Treatments duration affected negatively the callogenesis and/or callus growth, mainly for low levels of potassium and calcium, for both types of explants.

\section{REFERENCES}

ANDERSON, N.O. Reclassifications of the genus Chrysanthemum L. HortScience, v.22, p.313, 1987.

COCKSHULL, K. Chrysanthemum morifolium. In: HALEVY, A.H. CRC handbook of flowering. Boca Raton: CRC Press, 1985. v.2, p.238-257.

COOPER, H.D.; CLARKSON, D.T. Cycling of amino-nitrogen and other nutrients between shoots and roots in cereals - a possible mechanism integrating shoot and root in the regulation of nutrient uptake. Journal of Experimental Botany, v.40, p.753-762, 1989.

DEFÁVARI, D. Efeito do estado nutricional em $\mathrm{Ca}^{2+}, \mathrm{Mg}^{2+} \mathrm{e} \mathrm{K}^{+}$de matrizes de Bauhinia forficata Link na calogênese in vitro. Piracicaba, 2000. 72p. Dissertação (Mestrado) - Escola Superior de Agricultura "Luiz de Queiroz", Universidade de São Paulo.

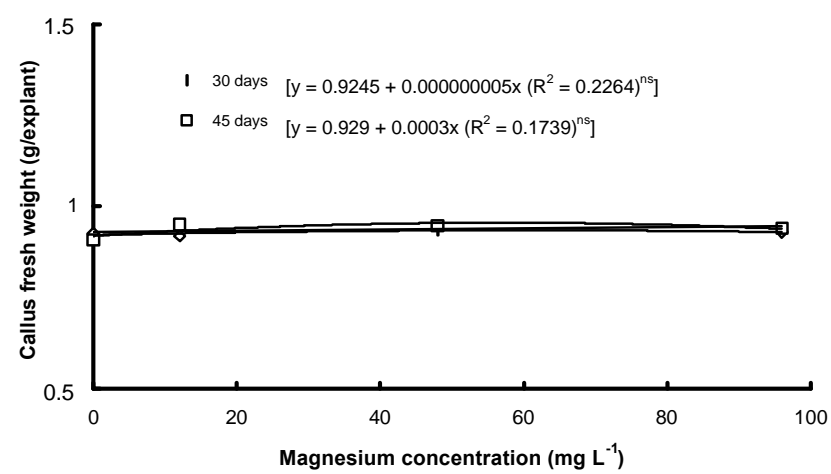

Figure 6 - Callus weight of Chrysanthemum morifollium cv. leaf explants in response to $\mathrm{Mg}$ concentration.

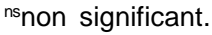

FRETT, J.J.; DIRR, M.A. Effect of nitrogen and calcium stock plant nutrition on Petunia $x$ Hybrida leaf and anther explant growth in vitro. Scientia Horticulturae, v.28, p.289-298, 1986.

GEORGE, E.F.; SHERRINGTON, P.D. Plant propagation by tissue culture: handbook and directory of commercial laboratories. Eversley: Exegetics 1984. 693p.

GOMES, F.P. Curso de estatística experimental. Piracicaba: Nobel, 1990 $468 p$

HE, D.G.; YANG, Y.M.; SCOTT, K.J. The effect of macroelements in the induction of embryogenic callus from immature embryos of wheat (Triticum aestivum L.) Plant Science, v.64, p.251-258, 1989.

HEPLER, P.K.; WAYNE, R.O. Calcium and plant development. Annual Review of Plant Physiology, v.36, p.394-439, 1985.

HOPKINS, W.G. Introduction to plant physiology. New York: John Wiley, 1995. 464p.

HUTCHINSON, J.F.; KAUL, U.; MAHESWARAN, G.; MORAN, J.R.; CRAHAM M.W.; RICHARDS, D. Genetic improvement of floricultural crops using biotechonology. Australiam Journal of Botany, v.40, p.765-787, 1982.

JESCHKE, W.D.; PATE, J.S.; ATKINS, C.A. Effects of $\mathrm{NaCl}$ salinity on growth development, ion transport and ion storage in while lupin (Lupinus albus L. vc. Ultra). Journal of Plant Physiology, v.124, p.257-274, 1986.

LEIGH, R.A.; WYN JONES, R.G. A hypothesis relating critical potassium concentrations for growth to the distribution and function of this ion in the plant cell. New Phytologist, v.97, p.1-3, 1984.

LIMA, A.M.L.P. Absorção de nutrientes e deficiências de macronutrientes e boro no crisântemo (Chrysanthemum morifolium Ramat) cultivar Golden Polaris. Piracicaba, 1987. 135p. Dissertação (Mestrado) - Escola Superior de Agricultura "Luiz de Queiroz", Universidade de São Paulo.

MARSCHNER, H. Mineral nutrition of higher plants. 2.ed. New York Academic Press, 1995. 889p.

MENGEL, K.; KIRKBY, E.A. Principles of plant nutrition. 4.ed. Bern: International Potash Institute, 1987. 655p.

MONTORO, P.; ETIENNE, H.; CARRON, M.P. Effect of calcium on callus friability and somatic embryogenesis in Hevea brasilinsis Mull. Arg: relations with callus mineral nutrition, nitrogen metabolism and water parameter. Journal of Experimental Botany, v.46, p.255-261, 1995.

SALINGER, J.P. Producion comercial de flores. Zaragoza: Acribia, 1991. $371 p$.

Received November 14, 2000 